\title{
Fulfillment in Continuity: The Orthodox Christian Theology of Biblical Israel
}

\author{
Demetrios E. Tonias
}

Concentrating on the Orthodox theology of biblical Israel within the context of fulfillment theology, the argument is that the early Church envisioned itself as the continuation of Israel of the Jewish Bible rather than its replacement. In the author's view, the current understanding of the distinction between replacement and fulfillment theology, the early Christian theological conception of the Church as Israel, and the ways in which both contemporaneous pagans and Jews viewed the nascent Christian faith support this assertion.

Keywords: Church, Israel, fulfillment, patristic, supersessionism, replacement, Orthodox, Judaism, Christianity, Liturgy.

\section{Introduction}

Scholars typically characterize the early Christian understanding of their relationship to biblical Israel as one in which the Church supersedes or replaces it. According to this supersessionist theology, the Church has supplanted Israel, defined as no longer having relevance in light of Christ's incarnation, death, and resurrection. Many scholars have embraced such a characterization of the patristic understanding of biblical Israel. This paper, however, suggests that a more nuanced "fulfillment theology" offers a better understanding of how the early Church viewed its relationship to the Israel of the Jewish Bible.

Fulfillment theology represents a Church that has not replaced, but rather has realized and continues the mission of biblical Israel. The early Church fathers did not see themselves as a "New Israel", but as Israel itself. For these early Christian exegetes, Abraham, Isaac, Jacob, and all the great figures of the Old Testament were proto-Christians who believed what Christians believed. Orthodox Christianity, for whom the early patristic thinking is both normative and formative, sees the Church as the "fulfillment of the Law and the Prophets". ${ }^{1}$ This paper will demonstrate the ways in which the

\footnotetext{
Demetrios E. Tonias, Ph.D., Adjunct Assistant Professor of Religious Studies, Hellenic College. Address: 178 Salem Street, Wakefield, MA 01880, e-mail: dtonias@hchc.edu.

1 The patristic corpus is indeed very broad and variegated both in style and in content. One can best categorize the Orthodox Church's reliance on patristic teaching as an adherence to the consensus patrum. Within the scope of this paper, the reader should note that various patristic figures and their writings presented in this text carry different weight in the Orthodox
} 
early Church (and thus, the Orthodox Church) viewed biblical Israel as an integral part of their community, whose head is Christ, the King of Israel.

I will survey the scholarship that describes the distinction between supersessionist and fulfillment theologies and the ways in which the latter better characterizes the early Christian attitude toward Israel. I will then discuss the implications of such a theology, both in terms of what it says about Israel and about the Church as Israel. To help inform and contextualize my argument, I offer an examination of the prevailing Greco-Roman view of the Church's relationship to the Judaism of their age and the Christian response to that understanding. Indeed, Christian identification with Israel was in many ways shaped by the Greco-Roman world's attempt to disassociate the early Christian community from its Jewish roots. I will then present the manner in which church fathers, from the Apostolic era and later, articulated this selfunderstanding. These Christian thinkers tenaciously argued that the Church was not some mere novelty emanating from Judea, but was the fulfillment and continuation of the Israelite narrative set forth in the ancient texts of the Jewish Bible. The patristic witness presented in this paper demonstrates that the early Church viewed biblical Israel, not in terms of replacement, nor even as some form of fulfillment that has reached its conclusion, but rather fulfillment in continuity-an eternal Israel that exists throughout time in the Church.

\section{Understanding the Terms}

\section{Supersession}

Supersessionism, as a concept, was unknown to the early Church Fathers. As Michael Azar notes, “"Supersessionism»-like other terms often employed in the study of patristic-rabbinic interaction-is a term ultimately foreign to the ancient writers themselves". ${ }^{2}$ R. Kendall Soulen articulates the standard, contemporary understanding of supersessionism as one in which, "the «spiritual» church is destined from all eternity to replace carnal Israel in God's plans". ${ }^{3}$ Such a general assessment of the Church's theological understanding of the biblical narrative, Israel, and Judaism requires considerable refinement when one attempts to locate supersessionism in early Christian thought in general, and that of the Orthodox Church in particular.

Church's theological outlook. Their value, in terms of this presentation, lies in their support of the early Christian witness that saw the Christian community as both the fulfilment and continuation of biblical Israel.

2 Michael G. Azar, “Origen, Scripture, and the Imprecision of «Supersessionism»”, in: Journal of Theological Interpretation 10 (2/2016), p. 157.

3 R. Kendall Soulen, The God of Israel and Christian Theology, Minneapolis, Fortress Press 1996, p. 19. 
Nevertheless, the contemporary Jewish-Christian theological dialogue is centered on the perceived supersessionist tendencies of the Church, which Adam Gregerman defines as "the belief that the Old Covenant was canceled by God, to be replaced by the far superior New Covenant". ${ }^{4}$ Soulen observes that critics of supersessionism argue that this teaching does violence to "God's free, irrevocable election of Israel as the people of God". 5 Soulen adds that, "the problem of supersessionism turns on the church's capacity to acknowledge the abiding religious significance of Israel's corporeal election and hence the abiding religious significance of the distinction between Gentile and Jew". 6

For early Christian thinkers, there was little argument with the "irrevocable election of Israel as the people of God". The religious significance of Israel, however, was dependent upon the characteristics that defined both Israel and Israelites. From the earliest moments of Christian thought, the Church viewed itself as the fulfillment of the Old Testament narrative, and thus Israel itself. Fulfillment, therefore, unlike supersessionism, does not suggest that "God had repudiated God's promises to Israel". ${ }^{7}$ Rather, these promises find their fulfillment in the Church that is Israel.

\section{Replacement or Fulfillment}

The New Testament text clearly supports the understanding that the Church is the fulfillment of God's covenantal relationship with Israel (e.g., Mt. 1.22; Lk. 4.21; Acts 7.17; Rom. 8.4). Within the context of Nostra Aetate, the Roman Catholic Church emphasized that God's promises to Israel "were fulfilled with the first coming of Christ". ${ }^{8}$ Furthermore, the Old Testament relationship of God with Israel was "a figure of that new and perfect covenant, which was to be ratified in Christ, and of that fuller revelation which was to be given through the Word of God Himself made flesh". ${ }^{9}$ These statements, articulated in 1964 and a decade later in 1974, express a fulfillment theology that has gained traction in Roman Catholic circles, most notably in the work of Pope

\footnotetext{
${ }^{4}$ Adam Gregerman, "Superiority without Supersessionism: Walter Kasper, The Gifts and the Calling of God Are Irrevocable, and God's Covenant with the Jews", in: Theological Studies 79 (1/2018), p. 38.

5 R. K. Soulen, The God of Israel, p. 5.

${ }^{6}$ Ibidem, p. 11.

7 Ibidem, p. 9.

8 Commission for Religious Relations with the Jews, Guidelines and Suggestions for Implementing the Conciliar Declaration Nostra Aetate (December 1, 1974), http://www.vatican.va/roman curia/pontifical_councils/chrstuni/relations-jews-docs/rc_pc_chrstuni_doc_19741201_nostra-aetate_en.html (hereafter cited as Guidelines), viewed on March 11, 2019.

9 Lumen Gentium (November 21, 1964) 2, http://www.vatican.va/archive/hist_councils/ ii_vatican_council/documents/vat-ii_const_19641121_lumen-gentium_en.html, viewed on March 11, 2019.
} 
Benedict XVI (the former Joseph Cardinal Ratzinger). William Madges, referencing the Pope Emeritus' work, affirms this position and states that,

Ratzinger elaborated on this idea in a more focused way in Many Religions, One Covenant. There he stated that the "faith of Israel was directed to universality. Since it is devoted to the one God of all men, it also bore within itself the promise to become the faith of all nations". That promise, however, was brought to fulfillment with and in Jesus, whose mission was "to unite Jews and pagans into a single People of God in which the universalist promises of the Scriptures are fulfilled that speak again and again of the nations worshiping the God of Israel". ${ }^{10}$

Proponents of a fulfillment theology would agree with Soulen's criticism of supersessionism: any theological understanding that views the Church as a replacement of the biblical Israel, creates a distorted image of the Christian community in which it is "estranged from its proper context in the Scriptures of Israel and in public history" and "disconnected from the sweep of public history". ${ }^{11}$

\section{Old/New/Worse/Better}

Critics argue that supersessionism and fulfillment theology are two sides of the same coin. Madges references the work of Marianne Moyaert and Didier Pollefeyt who argue that, "fulfillment thinking remains kindred to replacement thinking". ${ }^{12}$ Harold Smith articulates a similarly dim view of the replacement/fulfillment distinction. He identifies the difficulty of both systems as one in which the "connotations of «replace» and «fulfill» range from one thing's cancellation of another (replacement) to the creation of fullness or success (fulfillment)" ${ }^{13}$

Although fulfillment language may appear to be softer than that of direct replacement, there is the implication that the fulfilled is more complete and therefore better than that which preceded it. Gregerman recognizes such a distinction, and notes that fulfillment theology "indicates that there is some lack in the Old Covenant that needs to be satisfied or some incompleteness awaiting completion, which can be done only through the New Covenant". ${ }^{14} \mathrm{He}$ adds that,

10 William Madges, "Covenant, Universal Mission, and Fulfillment", in: Studies in Christian-Jewish Relations 12 (1/2017), p. 3-4.

11 R. K. Soulen, The God of Israel, p. 5.

12 W. Madges, "Covenant, Universal Mission", p. 6.

13 Harold Smith, Supersessionism and Continuance: The Orthodox Church's Perspective on Supersessionsim, Philadelphia, University of Pennsylvania Press 2014, p. 248.

14 A. Gregerman, "Superiority without Supersessionism”, p. 55. 
terms such as "fulfillment" represent non-neutral differences between the Old and New Covenants. Their views should therefore be understood in terms of the good/better model. They do not denounce the Old Covenant or believe that its unfulfilled status renders it a bad covenant.

Such an understanding, as we will see below, is entirely consistent with the early Christian understanding of the Church's role as Israel. ${ }^{15}$

\section{Continuity or Separation}

Contemporary scholars use the term "parting of the ways", to describe the separation of the Christian community with Judaism. Such descriptions depict the Christian Church as something discontinuous with its Jewish antecedents - a new Gentile entity that constituted a New Israel. In antiquity, however, a religion had little to gain by expressing itself as something new. Judaism functioned as religio licita within the Roman Empire, in large measure, due to its historical pedigree. Christians, therefore, would look to their Israelite roots as evidence of such lineage. As F. J. E. Boddens Hosang puts it,

since pagans were interested in Judaism's supposed antiquity, Christianity sought to emphasize its continuity from Judaism, despite their differences in belief in Jesus of Nazareth. Jews were also admired for their wisdom (interpretation of dreams and knowledge of magic), courage, temperance, justice and piety, and Moses was considered an ideal leader. ${ }^{16}$

Early Christian apologists were quick to appropriate such attributes and personages to their community and proclaim themselves to be the fulfilled Israel of the Jewish Bible.

Continuity with Israel allowed early Christian authors, such as Justin Martyr, to claim a long "philosophical" tradition, certainly meaningful to his Hellenistic audience. Justin noted the variegated nature of philosophy and that Platonists, Stoics, Pythagoreans, and others all held different philosophical views. As A. D. R. Hayes points out,

Clearly for Justin the chain of truth in philosophy has been corrupted. No longer is philosophy practiced as it should be. Justin does know of an exception to this, however. He will reveal another chain of practitioners who have preserved faithfully the truth which leads to God—the prophets of Israel. ${ }^{17}$

15 Ibidem, p. 56.

16 Francina J. E. Boddens Hosang, Establishing Boundaries: Christian-Jewish Relations in Early Council Texts and the Writings of Church Fathers, Boston, Brill 2010, p. 4.

17 A. D. R. Hayes, “Justin's Christian Philosophy: New Possibilities for Relations between Jews, Graeco-Romans and Christians", in: Studies in Church History 51 (2015), p. 24. 
Despite Justin's appeals to an Israelite heritage, early Christians recognized that there was another community that claimed the mantle of Israel. As William Horbury describes it, there was "a Christian sense of accepted separation from the Jewish community". He sees this "clearly detectable in writings from about the end of the first century onwards, notably the Epistle of Barnabas", in which we find "the polemical claim that Israel has been dismissed from divine election and replaced by the church is likewise most clearly asserted from this period onward". ${ }^{18}$ Justin Martyr's identification of the Church with Israel in his Dialogue with Trypho, however, represents the broader consensus that Israel, far from being dismissed, is present in the Church which constitutes the fulfilled Israel. Nevertheless, Horbury is correct in his conclusion that, "external impulses towards separation therefore impinged on Christians from the majority Jewish community long before the Christians themselves were ready to envisage separate existence". ${ }^{19}$

Early Christians, however, continued to identify with Israel and saw themselves as the inheritors of the Abrahamic promise. ${ }^{20}$ According to John Karmiris, Christians regarded themselves as "not only those who are descendants of Abraham naturally or by blood, but also all who imitated his faith became members of the Church, constituting through faith the "true Israel $" .{ }^{21}$ Christians understood continuity as established through a bloodline of virtue through their acceptance of Christ as Messiah and God.

The followers of Jesus also found justification for this belief in the Jewish Bible, which they claimed as their own. Peter Richardson notes that, "in the prophetic writings the doctrines of election and of the remnant begin to be used to distinguish what is and is not Israel. The criterion of birth remains a factor, but faithfulness to the covenant of God is stressed increasingly". ${ }^{22}$

18 William Horbury, Jews and Christians in Context and Controversy, London, Bloomsbury Publishing 2006, p. 12-13.

${ }_{19}$ Ibidem, p. 13. Horbury sees the separation as a result of the "special loyalty of the Christian group to Jesus as messiah", rather than "Christian adoption of specially high Christology ... or on Christian attitudes to Torah and gentilic tendencies". Such distinctions are indeed a matter of scholarly debate. However, the Gospel narratives in general, and the Gospel of John in particular, indicate that Christ's claims to divinity constituted the central issue for the Jewish authorities.

20 See: Demetrios Tonias, "Sharing the Inheritance: An Orthodox Christian View of the Church as New Israel in the Context of the Contemporary Jewish-Christian Dialogue", in: Current Dialogue 53 (1/2012).

${ }^{21}$ John N. Karmiris, "Ecclesiology of the Three Hierarchs", in: The Greek Orthodox Theological Review 6 (2/1960), p. 159-60.

22 Peter Richardson, Israel in the Apostolic Church, London, Cambridge University Press 1969 , p. 4. Richardson adds that, "at the same time there is an incipient universalizing of Judaism, so that there is a dual possibility: a narrowing of the category «Israel» within Judaism, and an opening up of the same designation to some from outside. There is a distinction 
Put another way, for the early Church, there was an exegetical path to selfidentification as Israel.

Of course, such an interpretive maneuver also existed within the text of the New Testament. Indeed, in the earliest moments of the Gospel narrative, John the Baptist makes the Abrahamic claim to those gathered at the Jordan River that, "God is able from these stones to raise up children for Abraham" (Mt. 3.9). Richardson suggests that John's cleansing of sins in the Jordan was a "proselyte baptism which has for its presupposition that all Jews have forfeited their right to be Israelites, have become as Gentiles, and therefore have to be readmitted". Such a baptism implies that there was "a large degree of discontinuity between those who sought it and those who rejected it". ${ }^{23}$ Christians interpreted both the Jewish and Christian scriptural texts as indicating their continuity with the Israelite tradition and justifying their claim to the inheritance of the mantle of Israel, through their virtuous living.

Richardson asks the central question, "Can there be any continuity between the previous entity (or Israel) and its continuation after the Easter events?" He concludes that, "the Church is both continuous and discontinuous with Israel BC" ${ }^{24}$ Some contemporary scholars and theologians defend such a negative contemporary historical assessment. Isaac Rottenberg notes the current reaction against a fulfillment understanding of the Church and states that,

John T. Pawlikowski, following other Catholic scholars such as Rosemary Radford Ruether and Gregory Baum, challenges the traditional "fulfillment" concept as basically inaccurate and calls for new approaches in Christology which he believes will "profoundly alter Christianity's self-definition and make possible a more realistic relationship to Judaism and to all other non-Christian religions." The basic thrust of his proposal is that Christians ought to abandon the claim that in Jesus the messianic age has been inaugurated. ${ }^{25}$

Other scholars, however, agree that fulfillment theology more accurately reflects the early Christian opinion that the Church represents the natural fulfillment of the Israelite narrative and offers a more fruitful basis for future dialogue. Most notably, Joseph Cardinal Ratzinger (later Pope Benedict XVI) declared that, "we say that the mission of Jesus is to unite Jews and pagans

between these two tendencies, however: the one is based on ritual and ethical standards and is present and observable; the other is an eschatological conception".

23 Ibidem, p. 5-6.

24 Ibidem, p. 6-7.

25 Isaac C. Rottenberg, "Fulfillment Theology and the Future of Christian-Jewish Relations", in: The Christian Century 97 (3/1980), p. 66. 
into a single people of God in which the universalist promises of the Scriptures are fulfilled that speak again and again of the nations worshipping the God of Israel". ${ }^{26}$ Orthodox scholar Thomas Hopko agrees with Ratzinger's assessment and argues that, "the "fulfillment» understanding of Christianity [cannot] be abandoned without the destruction of the Christian faith". ${ }^{27}$

For his part, Madges repeats the concerns of some scholars when he contends that, "Ratzinger's heavy emphasis on the continuity between Israel and the Church, understood in terms of promise-fulfillment, robs Israel/ Judaism of its independent identity" ${ }^{28}$ Madges and others conclude that much work still needs to be done in order "to clearly articulate" what the term fulfillment means. ${ }^{29}$

By comparison, Edward Kessler, speaking from the Jewish perspective, "welcomes ... the assertion that «the New Covenant for Christians is therefore neither the annulment nor the replacement, but the fulfillment of the promises of the Old Covenant»". To this positive assessment he offers a "warning [that] fulfillment easily slides into replacement and substitution theory is alive and well in the pews". ${ }^{30}$

\section{The Church as Israel}

The Christian community of the first and early second centuries did not develop in a vacuum. While early Christian authors were aware of and noted the ways in which their understanding of Israel diverged from historic Judaism, they still attempted to associate themselves with the Israel of scripture. Hayes frames the question of Christian self-understanding well when he states that, "identity is always a complicated and negotiated reality, whether personal or communal, and this is certainly true for Christian identity in the second century CE". ${ }^{31}$

The Christological claims and diverse ethnic makeup of the early Christian community complicated such a self-identification with Israel. When authors such as the Apostle Paul in the first century, or Justin Martyr in the second, attempted to reconcile the Israelite faith with the philosophical and cultural norms of the Hellenistic world they did so, "not in order

${ }^{26}$ Joseph Cardinal Ratzinger, Many Religions - One Covenant: Israel, the Church, and the World, San Francisco, Ignatius Press 1999, p. 10.

27 I. C. Rottenberg, "Fulfillment", p. 66.

28 W. Madges, "Covenant, Universal Mission”, p. 7.

29 Ibidem, p. 10.

30 Edward Kessler, "The Gifts and the Calling of God are Irrevocable"-Press Conference. https://www.ccjr.us/dialogika-resources/documents-and-statements/analyses/crrj-2015 dec10/kessler-2015dec10, viewed on March 11, 2019.

31 A. D. R. Hayes, “Justin’s Christian Philosophy”, p. 14. 
to supplement but to reinforce and modify Jewish theology, producing a version of Christianity that appears more attractive and intelligible to both Graeco-Romans and Jews". ${ }^{32}$ The Christian apologetical exercise was not a refutation of biblical Israel, but rather an articulation of what they believed constituted Israel-especially in relation to competing notions of Israel, both from Jews and pagans.

Indeed, reconciling divergent views within the context of Second Temple Judaism was nothing new. As the well-worn expression goes, "we do not speak of Judaism at the time of Christ, but Judaisms". William Horbury comments on the diverse nature of Judaism at the time of Christ and notes that, "diversity rather than unity in the Jewish practice and belief of the Second Temple period has been repeatedly discerned and stressed in the last thirty years". ${ }^{33}$ Sadducees and Pharisees argued about the resurrection. The community in Qumran that produced the Dead Sea Scrolls spent a considerable amount of time explaining their own unique positions. As Alan Crown puts it,

the Judaism of the late Second Temple period was richly pluralistic - latitudinarian - an amalgam of many streams of thought and practice from the Diaspora with its various languages through to the local philosophies and mystical ideas. It is now quite clear that Christianity in its birth century was part of that pluralism. ${ }^{34}$

What has become clear is that each group in the Second Temple period regarded itself as the Israel of the Jewish Bible. The Christian comprehension of Israel may have been more radically divergent than other expressions of Judaism at the time and the ethnic makeup of their community increasingly non-Jewish. Their claims to a true interpretation of the Israelite faith, however, were well within the tradition of contemporaneous Jewish "apologetics".

Horbury correctly states that Christians

rapidly developed a corresponding sense of themselves as essential Israel, perceptible in such titles as "the saints" and "the church of God", and somewhat comparable with the self-awareness of the Qumran community; their Gentile adherents had been made subject to the messiah of Israel (Rom. 15.12). ${ }^{35}$

In the minds of the early Christian authors, the "essential Israel" is a fulfilled Israel communicated first by Christ and later by the Apostle Paul.

32 Ibidem, p. 20.

33 W. Horbury, Jews and Christians, p. 3.

34 Alan D. Crown, "Judaism and Christianity: The Parting of the Ways", in: Alan J. Avery-Peck et al. (eds.) When Judaism and Christianity Began: Essays in Memory of Anthony J. Saldarini, Boston, Brill 2004, p. 547.

35 W. Horbury, Jews and Christians, p. 12. 
B. Ioannidis, connects this scriptural understanding of Israel with that of the early Church. He writes that the nascent Christian community saw itself not as a Church of the New Testament, but rather the Church of the Old Testament in which,

the Lord did not come to abolish, but to complete what was revealed in the Old Testament by God to His people and through them to the whole of mankind. This perpetuated Church of the Old Testament was fully organized, having a priesthood, sacrifices, ceremonies, and certain religious and moral teachings. This Church is the very nation of Israel, which was a theocratic nation, so that Church and Nation were identical. ${ }^{36}$

Put another way, for the first century church, the Israel of the two covenants was one and the same.

Richardson contends that, "The word «Israel» is applied to the Christian Church for the first time by Justin Martyr c. A.D 160. It is a symptom of the developing take-over by Christians of the prerogatives and privileges of Jews". Richardson concludes that, "Justin gives accurate expression to a long-standing tendency to increase the degree to which Christianity views itself as the heir of all which Israel once possessed". ${ }^{37}$ In reality, Justin recognized something which Christians always believed - they and the Church constituted Verus Israel.

\section{Greco-Roman Attitudes toward Christianity}

The attitudes of non-Christians toward the earliest followers of Jesus Christ and the associated Christian response to these assessments inform our understanding of how Christians viewed themselves. The Greco-Roman perception of Christianity is particularly informative, since it represents a thirdparty opinion of Jewish and Christian competing claims.

In the years both before and after the destruction of the Second Temple in Jerusalem by Titus' overzealous troops, commentators, such as the second century Greek philosopher Celsus, saw little difference between Jews and Christians whom he viewed as, "clustering bats or ants coming out of a nest, or frogs holding council round a marsh, or worms assembling in some filthy corner, disagreeing with one another about which were the worse sinners" ${ }^{38}$ Celsus' negative assessment was consistent with that of the

36 J. N. Karmiris, "Ecclesiology of the Three Hierarchs", p. 160-61. See footnote 73 in which Karmiris references, B. Ioannidis, The Kingdom of God According to the Teaching of the New Testament, Athens, 1955, p. 48-49.

37 P. Richardson, Israel in the Apostolic Church, p. 1.

38 William Hugh Clifford Frend, "The Old Testament in the Age of the Greek Apologists A.D. 130-180”, in: Scottish Journal of Theology 26 (2/1973), p. 130. 
Greco-Roman world at large. Boddens Hosang attributes such resentment of Judaism by the masses "to its inherent strength and resistance to assimilation with Hellenism", and adds that "despite the supposed hatred of Jews, the antiquity of their faith was greatly admired". ${ }^{39}$

In the Roman world, novelty was not a religious asset $-\mathrm{a}$ fact with which early Christian apologists such as Origen were well acquainted. As Louis Feldman observes,

the attack on Christianity in pagan literature was on two fronts: first, it was the first religion devoid of a nationalistic connection; and second, it was new and had no real roots in the past. In effect, the Christians had severed their links both with their pagan and their Jewish past. ${ }^{40}$

Justin Martyr, Origen, and others recognized this problem and were quick to address it in defense of their perceived historic roots. With this defense in mind, Feldman further notes that, "it was only by insisting that Christianity was a continuation, and indeed a logical climax, of Judaism that Origen was able to meet these charges, just as Eusebius was later to do in his Praeparatio Evangelica". Feldman rightly points out that Christianity defended its Israelite roots against both external (pagans and Jews) and internal (Marcionites) foes. ${ }^{41}$

The argument over antiquity was central to Christian self-understanding as Israel. Christian identification as a "New Israel" would have done little to dispel notions that the followers of Jesus of Nazareth constituted a novelty in the Greco-Roman religious milieu. In Roman society, the value of a culture or system of thought was only as great as its antiquity. Indeed, a major part of Josephus' project, to offer an apology for the Jewish people and their religious system of thought, was to testify to its antiquity. ${ }^{42}$

Christians, therefore, had to appeal to the Greco-Roman sense of legacy to obtain religious legitimacy in the eyes of the public at large. Hayes argues that Justin described Christianity as a philosophy, in part, because of the "illegality of converting to any novel sect, which was seen as betraying one's Greco-Roman roots". Therefore, if Christianity were a philosophy and not a religion, Justin would be able,

at least theoretically, to circumvent suspicions of conversion because the path he follows is not a private cultic devotion but is one

39 F. J. E. Boddens Hosang, Establishing Boundaries, p. 3-4.

40 Louis H. Feldman, “Origen's «Contra Celsum» and Josephus' «Contra Apionem»: The Issue of Jewish Origins”, in: Vigiliae Christianae 44 (2/1990), p. 107.

${ }^{41}$ Ibidem, p. 108. Marcion of Sinope (d. 160) was a first to second century Christian who rejected the Jewish Bible and any historical connection with Judaism.

42 Ibidem, p. 109. Indeed, when Celsus and others questioned Jewish claims to antiquity, they similarly impugned any Christian claims. 
of devotion to the universal truth, recorded in the ancient writings of the prophets, and taught by Christ, who approached God in truth and righteousness, as all philosophy ought to do. ${ }^{43}$

While Celsus argued that Jews lacked historical roots, his condemnation of Christianity was even stronger in that he argued that Christians weren't even good Jews. Celsus employed the device of a rhetorical Jewish interlocutor whose objections to Christianity the philosopher used in his polemic against the Christian religion. Lincoln Blumell describes Celsus' Jewish argument against Christianity as one in which

he never marshals any thorough attack but he is able to capture the essence and the key points of the scriptural assault; the Messiah was not to suffer and die but to come in great power. This insight is particularly significant because it shows that disputes over scriptural interpretation and fulfillment of prophecy with regard to Christ were prominent at the end of the second century. ${ }^{44}$

Daniel Boyarin argues that within Judaism itself, there was a distinction as to who and what constituted Israel. Boyarin cites Mishna Niddah 4.2 which suggests, "that «Sadducees» were not considered «Israel»". He offers the qualification that, "in this instance on grounds of ritual difference, not doctrine". ${ }^{45}$ The concern of Greco-Roman authors, such as Celsus, was neither ritual nor doctrinal, but antiquity and authenticity. It was into the waters of this debate that the earliest Christian authors waded and in which Jews and pagan Gentiles offered their response. As Boyarin further explains,

Jewish sectarianism as a form of decentralized pluralism by default had been replaced by the binary of Jewish orthodox and Jewish heretics: the latter comprising those who are Jews and say the wrong things and may therefore no longer be called «Israel». «Verus Israel», we could say, has been invented simultaneously, perhaps not coincidentally, by the Rabbis and the Gentile Christians. ${ }^{46}$

Conversely, adherents to the Greco-Roman religious cult, such as Celsus, questioned any association between Christianity and the God of Israel. Feldman describes Celsus' rebuke as one in which he

attempted to undermine Christianity's legitimacy by arguing that the Christians did not possess continuity with Judaism, that their

\footnotetext{
43 A. D. R. Hayes, "Justin's Christian Philosophy", p. 26.

${ }^{44}$ Lincoln Blumell, "A Jew in Celsus' True Doctrine? An examination of Jewish Anti-Christian polemic in the second century C.E”, in: Studies in Religion 36 (2/2007), p. 308.

45 Daniel Boyarin, “Justin Martyr Invents Judaism”, in: Church History 70 (3/2001), p. 443.

46 Ibidem, p. 447-448.
} 
laws had no traditional sanction, and that therefore they lacked national legitimacy. ${ }^{47}$

Christians took such accusations seriously and the response to them illustrates, in large measure, why the early Church was so vociferous in its refutation of Marcion's rejection of the Jewish Bible and any other attack on its historical Israelite claims-whether external or internal.

Feldman goes on to say that if Christians failed to refute Marcionism, they would only support the contention of Celsus and others that Christianity was a novelty. Feldman argues that,

the only way ... to establish Christianity's legitimacy was by giving it a historical basis, and the only historical basis was through demonstrating continuity with Judaism and through emphasizing that Christianity marked a religious-Celsus would call it a philosophic-revolt against Judaism, not a break with the Jewish people. ${ }^{48}$

\section{Christian Israelite Self-Understanding}

\section{New Testament}

The Christian defense of their Israelite self-understanding begins with the New Testament text. Rottenberg declares that,

the New Testament everywhere contains fulfillment language. In the Christological context, fulfillment terminology is used to assert that in Jesus of Nazareth, God acted in an ultimately decisive way in history; used in this way, fulfillment language reflects the fait accompli aspects of the Christian faith. ${ }^{49}$

The declaration of Christ in the Gospel of Matthew, "Do not think that I have come to abolish the Law or the Prophets; I have not come to abolish them but to fulfill them", is certainly the most overt association of Christ as the fulfillment of the Old Testament prophecies and continuity with scriptural Israel (Mt. 5.17). Matthew, however, was not the only evangelist to make such an association. As Frend notes, "Luke, though writing for a Hellenistic or Hellenistic-Jewish official, always sought to demonstrate wherever possible that Jesus or John the Baptist was fulfilling Scripture". ${ }^{50}$

${ }^{47}$ L. H. Feldman, “Origen's «Contra Celsum»", p. 108.

48 Ibidem.

49 I. C. Rottenberg, "Fulfillment Theology", p. 66.

50 W. H. C. Frend, “The Old Testament”, p. 132. Frend cites three examples in Luke. "Thus, John's mission was justified, as it is written in the words of Esaias the prophet' (Lk. 3.4) and Jesus is recorded as opening his mission at Nazareth with the words, "This day is Scripture fulfilled in your ears» (Lk. 4.16). More than once he warns his hearers to the effect that «this generation shall not pass away until all be fulfilled» (Lk. 16.17)”. 
The New Testament association of Jesus with the prophetic Messiah - the anointed one who would redeem Israel - is central to the scriptural identification of the Christian Church with Israel. Rottenberg explains that,

the Christological claims of the New Testament can hardly be overestimated. We are told not only that time has been fulfilled, but also that in Jesus Christ the law and the prophets have been fulfilled. In Jesus, claim the early Christians, all the promises of God find their «Yes» (2 Cor. 1.20). ${ }^{51}$

Justin Martyr offered a similar argument in the second century when he told the Jew Trypho that the "latter prophecies refer to Christ and the nations, you should believe that the former refer to Him and them in like manner" (Dial. 123.1). Larry Hurtado correctly concludes that, "early proto-orthodox Christians such as Justin were absolutely convinced that the Old Testament was a massive reservoir of characters and events that pointed ahead to Jesus". ${ }^{52}$

Bogdan Bucur observes that the New Testament text associates Christ not only with the Old Testament prophecies, but also with the God of the Jewish Bible. He notes that,

the Gospel of John, for instance, identifies the kyrios in Isaiah's vision with the kyrios of Christian worship: Isaiah "saw his glory» (Jn. 12.41), just as «we have seen his glory» (Jn. 1.14). Similarly, Paul terms the crucified one as «the Lord of glory» (1 Cor. 2.8), and the Book of Revelation extends the thrice-holy hymn sung by Isaiah's seraphim to the Son.

He cites recent research that points to

a growing segment of scholarship on Christian origins-scholars associated with the so-called New Religionsgeschichtliche Schule, but also older scholarship-that traces this second-century "YHWH Christology" or "Christology of Divine Identity" back to the writings of the New Testament. ${ }^{53}$

If the New Testament authors promulgated a "YHWH Christology" the only logical conclusion for early Christians was that they constituted $\mathrm{YH}$ WH's people, Israel.

51 I. C. Rottenberg, "Fulfillment Theology”, p. 66.

52 Larry W. Hurtado, Lord Jesus Christ: Devotion to Jesus in Earliest Christianity, Grand Rapids, W.B. Eerdmans 2003, p. 573-574.

53 Bogdan G. Bucur, "Justin Martyr's exegesis of Biblical Theophanies and the Parting of the Ways between Christianity and Judaism", in: Theological Studies 75 (1/2014), p. 46-47. 
Fulfillment in Continuity: The Orthodox Christian Theology of Biblical Israel The Epistle of Barnabas

The Epistle of Barnabas (dated from 70-132 CE) is explicit in its rejection of any Jewish claims to a covenantal relationship with God. In this text, the author addresses his reader and states,

Moreover, I ask you this one thing besides, as being one of yourselves and loving you all in particular more than my own soul, to give heed to yourselves now, and not to liken yourselves to certain persons who pile up sin upon sin, saying that our covenant remains to them also. Ours it is; but they lost it in this way forever, when Moses had just received it (Barn. 4). ${ }^{54}$

Joel Marcus claims that, "most of the Christians we know about from the early centuries concur with Barnabas that Israel has lost its status as God's covenant people and has been replaced by the church". ${ }^{55}$ Such a broad declaration demands more refinement. Replacement, unlike fulfillment, does not imply inheritance. The above referenced citation from the Epistle of Barnabas is clear that the Church has not replaced the Israelite covenant, but rather taken ownership of it- "ours it is; but they lost it". Richardson states the Epistle's "rhetorically clever hermeneutic argued that everything "theirs» was "ours", in opposition to Christians holding a two covenant approach that stated it was "theirs and ours»". ${ }^{56}$ Richardson argues that Barnabas promoted a belief that "Christianity had superseded Judaism". The statement that "theirs is ours", however, implies not supersession, but ownership.

\section{Clement of Rome}

As one of the prominent Apostolic Fathers, Clement of Rome (d. 99 CE), like his contemporaries, viewed the Church in terms of its Israelite antecedents. Frend observes that, Apostolic Fathers such as Clement of Rome, believed that "the New Covenant of Christianity was a continuation of the Old, and that the ethic and organization of Israel portrayed in the one passed over en bloc to the other". He adds that Clement and texts like the Epistle of Barnabas, saw Christianity as "the natural fulfillment and prolongation of the prophetic tradition of Judaism". ${ }^{57}$ Thus, the Church has fulfilled the prophetic witness and now continues the Israelite mission.

\footnotetext{
54 Joseph Barber Lightfoo et al., The Apostolic Fathers: Greek Texts and English Translations of their Writings, 2nd ed., Grand Rapids, Baker Book House 1992.

55 Joel Marcus, "Israel and the Church in the Exegetical Writings of Hippolytus", in: Journal of Biblical Literature 131 (2/2012), p. 386.

56 Peter Richardson, "The beginnings of Christian Anti-Judaism, 70-C. 235", in: Steven T. Katz (ed.), The Cambridge History of Judaism: Volume 4: The Late Roman-Rabbinic Period, Cambridge, Cambridge University Press 2006, p. 249.

57 W. H. C. Frend, “The Old Testament”, p. 134.
} 
One can find evidence of this understanding in 1 Clement, in which the first century hierarch quoted extensively from the Jewish Bible. Clement associates the faith and hospitality of Old Testament figures as diverse as Abraham, Lot, and Rahab with the virtue that Christ called his followers to exhibit and do "that which is written" (1 Clem. 10-13). For the Bishop of Rome, the Christians of Corinth, to whom he directed his letter, stood in line with the proto-Christians of ancient Israel. Fulfillment, therefore, did not mean the end, but the beginning. Clement of Rome and the Church fathers of subsequent generations understood the Church in terms of fulfillment in continuity.

Ignatius of Antioch

Ignatius of Antioch (d. 107 CE) was a late, first century bishop who offers a profound insight into first century Christian thought. His writings reflect a church with a fully developed priesthood, centered around a local bishop (Ign. Phld. 4:1). In his letter to the Magnesians, he wrote, "For if even unto this day we live after the manner of Judaism, we avow that we have not received grace: for the divine prophets lived after Christ Jesus". (Ign. Magn. 8:2). In the same epistle, the bishop of Antioch puts it another way: "For Christianity did not believe in Judaism, but Judaism in Christianity, wherein every tongue believed and was gathered together unto God" (Ign. Magn. 10:3). For Ignatius, it was the contemporaneous expression of Judaism that was out of step with the Israelite faith of the prophets, not Christians who represented the fulfillment and realization of their prophecies.

\section{Melito of Sardis}

Melito of Sardis (d. 180) was the bishop of Smyrna and an influential Christian thinker of the second century. One of his most famous texts is his exposition On the Passover (Peri Pascha), which follows the form of a Jewish Haggadah and is replete with overt typological associations to the Jewish Bible. As Bucur explains, Melito

identifies Jesus as the one who guided Israel in a pillar of fire, fed his people manna from heaven and water from the rock, and gave the Law on Horeb, and he generally assumes his readers' familiarity with the same type of Christological rereading of the story of Israel from Abraham to the conquest of the land and further to the times of kings and prophets. ${ }^{58}$

Hurtado makes the same observation regarding Peri Pascha. He notes that, "Melito's sermon shows us one of the major means by which the sweep-

58 B. G. Bucur, "Justin Martyr’s exegesis”, p. 45. 
ing portrayal of the Old Testament as full of references to Jesus was widely disseminated and celebrated in the second-century Christian circles in which the Old Testament was revered as Scripture". ${ }^{59}$ In his text on Pascha, the Bishop of Sardis emphasized Christian continuity with the Israelite narrative when he declared, "Thus the mystery of the Lord, prefigured from of old through the vision of a type, is today fulfilled and has found faith, even though people think it something new. For the mystery of the Lord is both new and old" (Mel. Pascha 57).

Melito simply reflected the prevailing attitude of Ignatius, Clement, and others who operated in a world where the New Testament canon was not yet codified and "scripture" meant the Jewish Bible. Any position that rejected the notion that the Christian Church constituted Israel would be swimming upstream against the prevailing understanding that the Church fulfilled not only the prophetic witness but also all the Old Testament biblical tropes.

\section{Hippolytus of Rome}

Hippolytus (d. 235) was a prolific author who wrote on a variety of exegetical, doctrinal, and ecclesiastical topics. The Roman prelate saw an imminent realization of the prophetic witness of the Jewish Bible. Marcus writes that, "Hippolytus", writing in the late second and early third centuries, "sees the present as the time of fulfillment, in which the ancient prophecies of Israel's restoration are being realized; he therefore calls on Israel to enter into her salvific destiny through believing in Jesus". Hippolytus' commentary on the Song of Songs suggests a prophetic fulfillment that proclaims a Christian self-identification with Israel.

From the above, we can see that this close identification with Israel led Hippolytus to call for a mission to the Jewish community of his day. As Marcus explains, Hippolytus emphasized "what a small step it is from Judaism to Christianity, since the law and the gospel are so intertwined" ${ }^{60} \mathrm{He}$ articulated a typological model in which, "Isaac stands for God, Jacob for the church, and Esau for the Jewish people" ${ }^{61}$ In this light, Jacob, who became Israel, constituted the Christian Church. In a similar fashion, Hippolytus associated the Christian liturgical worship with that of the Temple. He described the Christian practice of prayer at the hours as one in which, "in the Old [Testament], the Law prescribed that the shewbread should be offered at every hour as a type of the Body and Blood of Christ; and the slaughter of

59 L. W. Hurtado, Lord Jesus Christ, p. 45.

60 J. Marcus, "Israel and the Church", p. 396.

61 Ibidem, p. 397. 
the speechless lamb is this, a type of the perfect lamb”. ${ }^{62}$ Far from presenting a radical, new replacement for Israel, the bishop suggested that the Israel of the New Testament Church lived in close proximity to the Israel of the Old.

\section{Origen}

Origen (d. $253 \mathrm{CE}$ ) was one of the most influential and controversial Christian thinkers of his era and into the later centuries. Although he was a prolific author, many of his texts have been lost to antiquity. A good number of his writings were exegetical commentaries within which he expressed his understanding of the Church's relationship to Israel. For Origen, the two covenants formed a single entity as shown by the "practice of the Savior or His apostles, frequently quoting illustrations from the Old Testament [which] shows that they attribute authority to the ancients." ${ }^{63}$ Indeed, according to Origen, the two scriptural texts are so closely related that, "it would be tedious to collect out of all the passages in the Gospels the proofs by which the God of the law and of the Gospels is shown to be one and the same". ${ }^{64}$

Azar makes the observation that, "supersessionism is not a label that easily applies to Origen's thought". ${ }^{65}$ As Azar explains, "for Origen, the OT is not simply a prophetic or typological sourcebook that points forward to the events of the NT, a shadow waiting for reality". In this way, Origin "avoids taking the OT as simply containing types of NT events; rather, he looks to both as containing types of antitypes beyond history". ${ }^{66}$

As Azar properly notes, for early Christian authors such as Origen, "without sound exegesis and a virtuous life, neither the Old nor New Testaments properly reveals Christ to the soul of the reader in a way that contributes to one's spiritual advancement" ${ }^{67}$ For Origin, and other patristic figures such as John Chrysostom, an individual's virtue determined his or her status as an Israelite, not their ethnic background. As mentioned above, their understanding of Israel was grounded in John the Baptist's assertion that "God is able from these stones to raise up children for Abraham". (Mt. 3.9). Origen reflected an earlier tradition, as that of Irenaeus of Lyons (d. 202 CE) who, as Frend indicates, "cites the New Testament almost as often as he does the Old, and leaves no doubt that the two Testaments were knit together as a single scripture". ${ }^{68}$

${ }^{62}$ Hippolytus, On the Apostolic Tradition, trans. Alistair Stewart-Sykes, Crestwood, NY, St. Vladimir's Seminary Press 2001, p. 165.

63 On First Principles 4, 1; trans. ANF 4, p. 275.

64 On First Principles 4, 2; trans. ANF 4, p. 276.

65 M. G. Azar, "Origen, Scripture”, p. 158.

66 Ibidem, p. 159.

${ }^{67}$ Ibidem, p. 160.

68 W. H. C. Frend, "The Old Testament”, p. 148-149. 


\section{Justin Martyr}

Justin Martyr (d. 165 CE) was a second century Christian apologist who was one of the most strident advocates of Christian fulfillment theology. While Justin may have been a vocal proponent of the association of the Church with Israel, he was by no means the first. Bucur correctly observes that Justin was less of an innovator and more of a promulgator of an ancient tradition that saw in Jesus Christ the "Lord" of the Jewish Bible. ${ }^{69}$ Bucur agrees with Larry Hurtado who describes the early Christian association of Christ with the God of the Jewish Bible as one in which, "Justin did not originate the basic idea that the preincarnate Jesus could be found active in certain Old Testament passages". Although Justin broadens the associations of Christ with the God of the Old Testament, he "was essentially building upon a line of Christological argument already available. He reflects an approach to the Old Testament that had been a feature of devotion to Jesus during the first decades of the Christian movement". Furthermore, "his programmatic finding of the preincarnate Jesus in Old Testament passages is probably one of the traditions that helped shape Irenaeus's idea that Jesus is the full and final manifestation of the divine Logos who has been active throughout human history". ${ }^{70}$

In Justin's Dialogue with Trypho, the apologist offers a full-throated defense of his fulfillment theology with Trypho, an interlocutor who may or may not have been a real person. Whether or not Trypho was a living, breathing Jew at the time of Justin or a rhetorical construct, he reflects the martyr's impression of Jewish objections to Christian Israelite claims. In the Dialogue, Trypho voices his complaints and says,

This is what we are most at a loss about you that, professing to worship God and thinking yourselves superior to other people, you are separate from them in no respect and do not make your life different from the heathen, in that you keep neither the feasts nor the sabbaths, nor have circumcision; and, moreover, that though you set your hopes on a man that was crucified, you yet hope to obtain some good from God, though you do not do his commandments (Dial. 10.3). ${ }^{71}$

Despite the absence of so many of the external markers of Judaism, Justin continued to make the case that the Church was Israel. ${ }^{72}$

69 B. G. Bucur, “Justin Martyr's exegesis”, p. 45-46.

${ }^{70}$ L. W. Hurtado, Lord Jesus Christ, p. 577.

${ }^{71}$ For more on this exchange see: Demetrios Trakatellis, "Justin Martyrs Trypho", in: The Harvard Theological Review 79 (1/3/1986), p. 292.

72 The absence of such external markers of Judaism took place over time, especially after the destruction of the Second Temple in Jerusalem in $70 \mathrm{CE}$. This situation was more pro- 
After a long disputation, Trypho asks the Christian apologist, "What, then? Are you Israel?" In his response, Justin appeals to various figures of the Jewish Bible to support his position. "As therefore from the one man Jacob, who was surnamed Israel, all your nation has been called Jacob and Israel; so we from Christ, who begat us unto God, like Jacob, and Israel, and Judah, and Joseph, and David, are called and are the true sons of God, and keep the commandments of Christ" (Dial. 123.7). Justin's response was disconcerting to Trypho and his companions. L. W. Barnard describes this concern when he states that, "Trypho and his friends are worried by Justin's remark that Gentile Christians are the children of God and Israel itself". ${ }^{73}$

Justin was only following a pattern of self-identification and exclusion that was present in the rabbinic ideology of his age. Shaye Cohen states that, "this rabbinic ideology is reflected in Justin's discussion of the Jewish sects: there are Jews, i.e., the "orthodox, " and there are sects, among them the Pharisees, who scarcely deserve the name Jew" ${ }^{74}$ The debate in which Justin engaged with Trypho was the same in which Christians had engaged with Jews and the broader Greco-Roman society - namely, who is the true inheritor of the mantle of Israel?

Scripture was the battleground for this dispute. Justin articulated the long-held Christian understanding of salvation history in which the incarnation was "an eschatological event that brings the Biblical story to fulfillment". ${ }^{75}$ Jean Daniélou extends this thinking to the resurrection which early Christians considered to be "the eschatological event announced by the prophets of Israel". As a result, Christians believed that "they constituted the true Israel, the community of the New Covenant" ${ }^{76}$

Frend describes the manner in which the apologist expressed his understanding of Christian fulfillment of the Jewish Bible. He characterizes Justin's response to Trypho as

nounced at the time of Justin. Alan Crown notes that "... the process of Christian self-definition was beginning in that there was a developing group of people who called themselves Christians but who had not yet clarified their beliefs; nor were they identifiably very different from Jews, nor their religion from Judaism". A. D. Crown, "Judaism and Christianity", p. 552.

73 L. W. Barnard, “The Old Testament and Judaism in the Writings of Justin Martyr", in: Vetus Testamentum 14 (4/1964), p. 397.

${ }^{74}$ Cohen notes that, "All of the persistent sectarians" of "'Pharisees,' 'Sadducees,' and 'Christians' ... were cursed in the birkhat haminim". Shaye J. D. Cohen, "The Significance of Yavneh: Pharisees, Rabbis, and the End of Jewish Sectarianism", in: Hebrew Union College Annual 55 (1/1984), p. 49.

75 L. W. Hurtado, Lord Jesus Christ, p. 326.

76 Jean Daniélou, Wilfred J. Quinn, "A New Vision of Christian Origins: Judaeo-Christianity”, in: Cross Currents 18 (2/1968), p. 164-165. 
one of his best passages, [in which] he rounds off his argument with citations from the Old Testament in the ascending order of importance accepted by the Jews of the time, namely the Hagiographa, the Prophets and, finally, the Law. «You recognize them, Trypho? They are laid up in your scriptures, or rather not in yours, but in ours, for we obey them, but you, when you read, do not understand their sense». The claim that the Old Testament is «ours and not yours» was defended by interpreting events narrated there typologically. ${ }^{77}$

In the end, Justin was not concerned with Christianity superseding Israel he simply wanted to lay claim to its inheritance.

\section{John Chrysostom}

John Chrysostom (d. 407) was a late fourth, early fifth century priest and bishop and one of the most prolific homilists and authors in the Christian East. The Orthodox Church holds the preacher in high regard for his philanthropic and pastoral outlook. He also produced tracts that were at one time classified in the genre of Adversus Judaeos, but have now been more appropriately categorized under the title, Against Judaizing Christians. ${ }^{78}$ In many ways, John Chrysostom was engaged in the same debate as that of Justin with Trypho - namely, which party constituted the true inheritors of scriptural Israel.

In his congregation, there were a significant number of the faithful enamored with Judaism and Jewish customs. Reacting to this practice, John attempted to convince his community that they were the rightful inheritors of the Abrahamic covenant and were thus the true Israel..$^{79}$ In his references to the Patriarch Abraham, the Antiochene preacher stressed that virtue, not blood, defined relationship to the aged patriarch. He warns that Jews are not to seek "refuge in their forefathers" but rather "rest the hope of their salva-

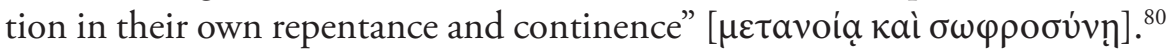

For Chrysostom, virtue was the blood that connected Christians to Abraham, his son Isaac, and his grandson Jacob/Israel. He acknowledged that Jews were not entirely cut off (at least initially) from their Abrahamic

\footnotetext{
77 W. H. C. Frend, «The Old Testament”, p. 142.

78 See: John Chrysostom, Discourses against Judaizing Christians, trans. Paul W. Harkins, The Fathers of the Church, Washington, Catholic University of America Press 1979, p. xxxi, note 47.

79 See: D. Tonias, Abraham in the Works ofJohn Chrysostom, Minneapolis, Fortress Press 2014.

${ }^{80}$ Chrys., hom. in Mt. 11, PG 57, 194; trans. NPNF I, 10, p. 66. Here Chrysostom makes reference to the cardinal virtue " $\sigma \omega \varphi \rho \sigma^{\prime} v \dot{v} \eta$ " and thus relates the practice of virtue to relationship with Abraham.
} 
roots. He nevertheless concludes that "by unbelief they were made aliens"

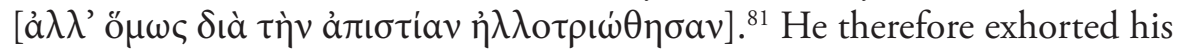
flock to imitate the virtue of the great patriarch and in this way become inheritors of his covenant with God, and in relation, the entire narrative of the Jewish Bible.

John made reference to the sons of Samuel and Aaron and asked his congregation what good was their biological relationship to their fathers. "For what were the sons of Samuel advantaged, tell me, by their father's nobleness, when they were not heirs of their father's virtue?" 82 Chrysostom argued that it was the failure of the Jewish people to adhere to universal categories of virtue, which the great Israelite saints possessed, that had cut them off from Abraham. Although the Jewish people "were sprung from those holy men ... they were neglecting the virtue of the soul" and it was this virtue that was the governing criterion for relationship with Abraham and thus all of Israel.

The Apostle Paul so greatly influenced John Chrysostom that one could argue John's theology was Paul's theology. In the preacher's vision of Christians as the fulfillment of scriptural Israel, he grounded himself in Paul's instruction to the church of Rome that, "they are not all Israel, which are of Israel" (Rom. 9.6).

\section{Liturgical Witness}

The Orthodox Church adheres to the maxim of lex orandi, lex credendi. If one understands that the rule of prayer is indeed the rule of belief, the manner in which the Orthodox Church employs scripture in its liturgical worship can offer insight into the way the liturgical authors sought to convey their understanding of fulfillment theology through the vehicle of corporate worship. The theology communicated in liturgy is wide and varied - encompassing everything from Christology to Soteriology. One can find the liturgical pronouncement of the Church as Israel throughout the feasts and services of Orthodox worship.

Patristic figures such as Ignatius of Antioch and Clement of Rome in the first century, Clement of Alexandria in the second, Eusebius in the fourth, and Germanus in the eighth (to name only a few, prominent examples) either directly or indirectly associated the Christian Church and its Eucharistic worship with that of the Jerusalem Temple. While the course of development of these associations is a point of scholarly debate, certainly by the time of Germanus they were fully formed. The Barberini Codex 336,

${ }_{81}$ Idem, hom. in Rom. 19, PG 60, 539; trans. NPNF I, 11, p. 494.

82 Idem, hom. in Mt. 9, PG 57, 181, trans. NPNF I, 10, p. 59. 
contemporaneous with Germanus, represents the oldest extant euchologion. This liturgical service book bears witness to the historic Christian association of the Church with the fulfilled Israel of scripture.

Some of these fulfillment references are scriptural in nature, such as the "Song of Simeon", which the celebrating priest or hierarch reads at the service of Vespers, as well as at a forty-day blessing of an infant. Simeon was an elder of the Temple who, upon seeing the Christ child, declared, "Lord, now let Your servant depart in peace according to Your word; for my eyes have seen Your salvation, which You have prepared in the presence of all nations: a light to enlighten Gentiles, and glory for Israel Your people" (Lk. 2.25-35). Throughout the sacred services, there is an implicit association of the Church faithful with the "people of Israel".

At the same blessing, the prayers trace the arc of salvation history when the mother presents the child to the priest in the Christian Temple as the Virgin Mary presented Christ to Simeon at the Second Temple in Jerusalem. The service references the "great voice of the Prophet Isaiah" (ó $\delta$ ì̀

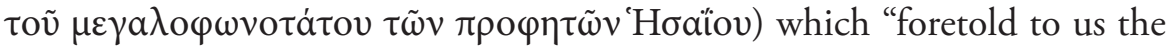
incarnation from a Virgin" and of Christ who became "a child of her for the salvation of men" ${ }^{83}$ From the first moments of life, the liturgical authors are sure to place the Christian faithful firmly within the master story of biblical Israel.

The Eucharistic rites of the Church also proclaim Christian ownership of the Jewish metanarrative. In the priestly prayer that begins the Liturgy of the Faithful, Basil of Caesarea echoes the language of the Prophet Zephaniah and proclaims Christ as the "King of Israel". ${ }^{84}$ The identification of Christ as the King of Israel, carries with it the association that the faithful in attendance are Israelites. This connection is even more direct in Basil's recapitulation of salvation history and his use of the first person plural pronoun in his post sanctus of the Anaphora. Basil addresses God in the prayer and states,

For You did not forever reject Your creature whom You made, O Good One, nor did You forget the work of Your hands, but because of Your tender compassion, You visited him in various ways: You sent forth prophets; You performed mighty works by Your saints who in every generation have pleased You. You spoke to us by the mouth of Your servants the prophets, announcing to us the salvation which was to come; You gave us the law to help us; You appointed angels as guardians. And when the fullness of time had

83 Mıкрòv Eủxoגó

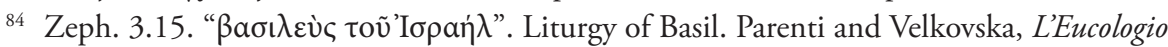
Barberini gr. 336, 2d ed, p. 62. 
come, You spoke to us through Your Son Himself, through whom You created the ages. ${ }^{85}$

The "us" in Basil's prayer places the Christian faithful firmly in the role of the scriptural Israelites to whom God and the prophets spoke.

Chrysostom's Eucharistic prayer conveys the same sense of Israelite continuity. In John's version of the prayer the priest declares just prior to the words of institution,

When He had come and fulfilled for our sake the entire plan of salvation, on the night in which He was delivered up, or rather when He delivered Himself up for the life of the world, He took bread in His holy, pure, and blameless hands, and, giving thanks and blessing, He hallowed and broke it, and gave it to His holy disciples and apostles, saying: Take, eat, this is My Body, which is broken for you for the remission of sins. ${ }^{86}$

The "entire plan of salvation" was "fulfilled for our sake" - that is for the Church as Israel. The patristic view of salvation history is thus fully ensconced within the principal liturgical rite of the Church.

Justin Martyr could not have articulated a more succinct, cogent, and coherent synopsis of his fulfillment theology than that which the priest offers at the prothesis, following the Behind the Ambo prayer. In Chrysostom's liturgy, just prior to the dismissal, the priest bows toward the prothesis table and declares, "Christ our God, You are the fulfillment of the Law and the Prophets. You have fulfilled the Father's entire plan of salvation. Fill our hearts with joy and gladness always, now and forever and to the ages of ages. Amen". There is no hint of a replaced or even New Israel, only that of a fulfilled Israelite Church. ${ }^{87}$

85 Liturgy of Basil. Parenti and Velkovska, L'Eucologio Barberini gr. 336, p. 65-66. The roots of Basil's prayer are, of course, scriptural. In this portion of the post sanctus, Basil makes reference to Dan. 3.34, Ps. 137.8, Lk. 1.78, Heb. 1.1, cf. 2 Chr. 36.15, Est. 927, Gen. 5.22, Lk. 1.70, Rev. 10.7, Acts 3.18, Is. 8.20, cf. Gal. 4.4, Eph. 1.10.

${ }^{86}$ Ibidem, p. 77.

${ }^{87}$ In fact, there are some liturgical references to the Church as a New Israel. These references, however, are more poetic than theological in nature. For example, at the Great Blessing of the Waters, a poem, attributed to Patriarch Sophronius of Jerusalem, declares

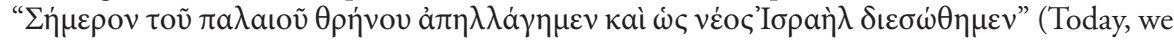

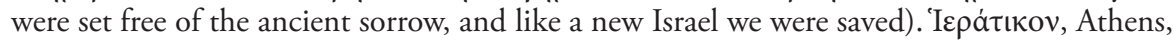
Greece, Apostolike Diakonia 1987, p. 252.

Similarly, at the Great Vespers of Palm Sunday, one of the kekragaria hymns commands

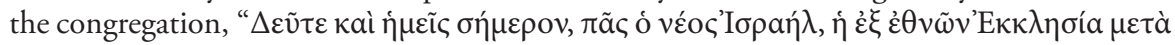

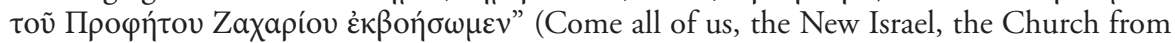

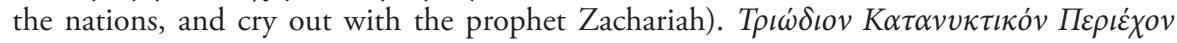

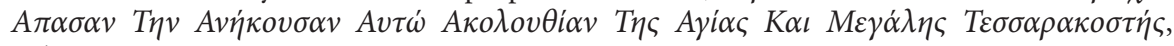
Athens, Greece, $\Phi \omega \varsigma$ 1967, p. 380. 
One can also see this sense of fulfillment at the Vespers celebrating the Monday of the Holy Spirit. The third kneeling prayer addresses the Holy Spirit as,

the never-failing spring, bursting with life and light, creative power co-eternal with the Father, You fulfilled surpassingly the plan for the salvation of humankind, shattering the unbreakable bonds of death and the bolts of Hades and trampling the throngs of evil spirits. $^{88}$

The emphasis on the divine economy and salvation history establishes the unity of the two halves of scripture and gives voice to the Church's claim that they are the inheritor of the Israelite blessings and privileges.

This same emphasis is present in the major sacramental rites of the Orthodox Church. At baptisms, God is invoked as the, "Lord of Sabaoth, the God of Israel, who heals every sickness and every wound" ${ }^{89}$ In the same rite, the priest asks God to, "Build him (her) on the foundation of Your Apostles and Prophets", and to bless the neophyte Christian "as You did bless the head of Your servant David the King through the Prophet Samuel", so that the newly baptized may "see the good things of Jerusalem all the days of his (her) life". ${ }^{90}$

This recounting of narrative is especially prevalent in the sacrament of marriage in which the author of the service wished to establish the couple's continuity with that of the marriages of the great figures of the Jewish Bible. In the sacrament, the priest asks God to bless the couple as he blessed Abraham and Sarah, Isaac and Rebecca, and Jacob and Rachel and to crown them in marriage as he crowned Joseph and Asenath, and Moses and Zipporah. ${ }^{91}$ Every couple thus becomes a part of the Israelite metanarrative. The sense of fulfillment and continuity is embodied in the Nicene-Constantinopolitan Creed which proclaims that the "Holy Spirit" spoke through the Prophets.

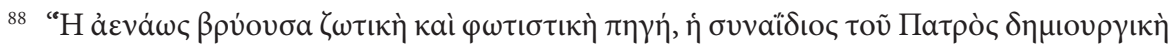

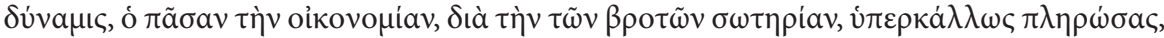

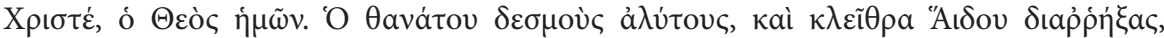

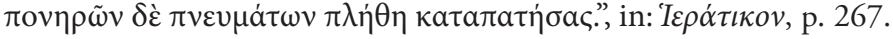

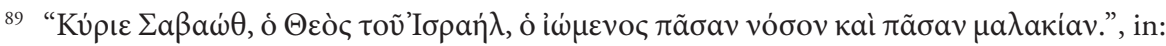

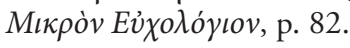

90 Ibidem, p. 92, 107.

91 In the Barberini Codex 336, the blessing follows that described in the text. The contem-

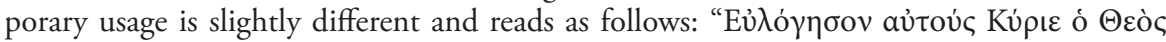

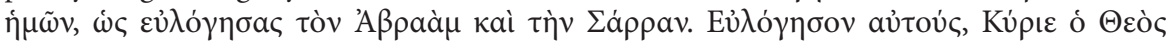

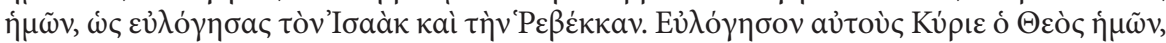

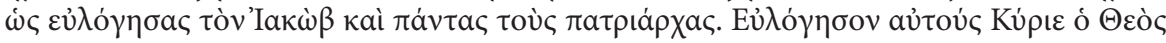

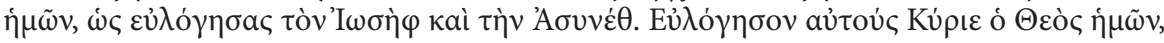

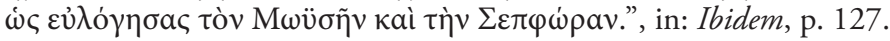




\section{Conclusion}

For many reasons, the designation of the early Church as supersessionist is, at best, misleading and, at worse, incorrect. The most compelling argument against supersessionism is that early Christians argued against such a notion. Early Christian thinkers did not believe that God had repudiated his promises to Israel, but that these promises found their fulfillment in the Christian Church. In the works of Pope Benedict XVI and others we see a welcome clarification of such a distinction - the absence of which misrepresents the way in which the primitive Church viewed itself.

One, however, should be conscious of painting with too broad a brush in dismissing supersessionism as a characterization of Christian attitudes. In the first instance, because there is a wide latitude in the definition of supersessionism with language that tends more toward fulfillment, rather than outright replacement. In the second instance, given the spectrum of later Christian interpretations (predominantly, but not exclusively, in the Christian West) it is possible, if not likely, to find language that advocates something akin to replacement theology. Such a view, however, is inconsistent with both early Christian and Orthodox theological understanding of Israel.

Leading figures in the early Church argued mightily in support of continuity with ancient Israel. A strict supersessionist theology would have delegitimized the Church in the eyes of the Greco-Roman world with which Christians competed both in the marketplace of ideas and for converts. The Church's refutation of Marcion, and others who categorically rejected the Jewish Bible, demonstrates the tenacity with which early Christians defended their Israelite roots. In addition, the Church opposed philosophers, followers of the old Greco-Roman religious order, and Jews who questioned their claims to Israelite inheritance.

To reinforce their position, Christians turned to both the Jewish and Christian scriptural texts. They regarded the Israelite story as their story, and although they did not appropriate every aspect of that narrative, they claimed ownership of the divine blessings and benefits contained therein. To be sure, such claims puzzled Greco-Romans and Jews alike. From the earliest moments of the Apostolic Church, however, Christians authors were steadfast in their assertion that the Christian Church fully constituted Israel and not some version of a New Israel. Indeed, their appeals to an "orthodox" interpretation of the text in opposition to other "heretical" beliefs was, as Shaye Cohen demonstrates, well within the norms of contemporaneous Judaism.

One thing on which Christians could agree was that they had no interest in being a novelty. In antiquity, as in all times, religions derived their 
moral and cultural authority from their historical legacy and assertion of longevity. Jewish apologists such as Josephus were well aware of such a consideration and Christians were equally cognizant of this reality. Christian authors went to great lengths to express the ways in which the new Christian faith was contiguous with biblical Israel. At every instance they sought to define the Jewish scripture as an inherently Christological text. To favor replacement over fulfillment would have undercut their own arguments. The patristic texts not only identify Christ with the prophetic witness, but with the God of the Old Testament. In the minds of the earliest Christian thinkers, the Gospels were simply the next chapters in a very old story.

The patristic understanding of the Old Testament and its relationship to the New was not only typological, but also historical. While there are numerous typological associations in which everything from the Church structure to the Virgin birth is prefigured in the passages of the Jewish scripture, there is also significant exegetical real estate devoted to supporting the historical continuity of the Church with Israel.

The increasingly non-Jewish character of the Church made such historical claims difficult, but not impossible. The Hellenistic world in which Christianity developed, steeped in Greek philosophical precepts, made virtue an attractive marker for Israelite citizenship. While virtue had no standing in the Jewish world, it had immense appeal in the Greco-Roman universe. Christians may have lacked the appropriate Israelite DNA, but they could always claim that they had more in common with the great figures of the Jewish Bible than their biological descendants. Any suggestion that the Church had replaced Israel would work against such a connection. Put another way, why would one appeal to philosophical agreement with a history that no longer had any value?

The Orthodox Church's liturgical witness gives voice to the early Church's fulfillment theology. The Jewish antecedents of Christian belief are present in services that have the closest historical proximity to the early Church. There is almost no hint of a New Israel in the prayers and hymns, only an emphatic declaration that the Church is Israel and its head is Christ, the King of Israel. Orthodox worship is eminently concerned with the presentation of salvation history. This history begins and ends with Israel. Indeed, perhaps there is no better endorsement of the Orthodox Church's embrace of a fulfillment theology than its assignment of feast days for the major Israelite saints - something absent in the Christian West.

The patristic and Orthodox understanding of fulfillment theology has much to contribute to the contemporary Jewish-Christian dialogue. The historic, theological understanding of the Church as biblical Israel, at the very least, has something positive to say about Israel. Debate over which 


\section{Demetrios E. Tonias}

Israel is the better Israel, in the end, misses the point. The question is not whether the Israel of Judaism is better than the Israel of Christianity or vice versa. The central issue is the same as it was in the first century: "what and who constitutes Israel?" Is Israel fulfilled and continued, but not ended or rendered irrelevant in Christianity? For that intractable question there may be no answer. However, a focus on supersessionist language does little to advance the dialogue.

The problem with supersessionism is that it asks all the wrong questions - a principal reason why the early Church avoided or qualified supersessionist language. The question is not whether the old covenant is bad, and the new covenant is good, but rather "what is the nature of covenant?" The question is not about the "parting of the ways", but what is the common spring from which both tributaries flow. An examination of fulfillment theology allows Jews and Christians to investigate these issues and others in a meaningful fashion that traces each faith tradition back to its point of origin, rather than seeking to identify a point of divergence.

The debate between Justin Martyr and Trypho is as meaningful today as it was in the second century. It was a debate over which party better represented Israel - something that was an internal Jewish question for quite some time. Despite the divergent positions of each party, and the challenging nature of the subject matter, the dialogue with Trypho was nevertheless a respectful one. Our present dialogue should be one in which Jews and Christians seek to determine the fullness of the biblical narrative and in which each party asks the Dialogue's central question of the other, "What, then? Are you Israel?" 